\title{
"Where, O Death, Is Your Sting?": The Resurrected Body, Its Cyborgnetic Future and the Advent of Christian Transhumanism
}

\author{
James McBride ${ }^{1}$
}

\begin{abstract}
The $21^{\text {st }}$ century's robotic revolution will have massive effects on human societies. Neuroscientists have experimented with the idea of preserving the brain after death through vitrifixation in the hopes of uploading the minds of individuals into the cloud or cyborgnetic bodies. However, the likelihood of duplicating the 86 billion neurons in the buman connectome is remote. Yet neuroscientists have had some success in connecting brain cells to robots, which echoes the philosophical question of "Brains in a Vat." This article addresses the consequences of such a development for Christianity. Since Christianity is predicated on resurrection and life everlasting, the transhumanist vision of connecting the human brain to cyborgnetic bodies, particularly if it becomes popular, poses a serious challenge. This article suggests a way in which Christianity may be able to incorporate that vision into Christian theology, leading to the advent of Christian transhumanism.
\end{abstract}

Keywords: Brain preservation; Robots; Resurrection; Cyborgnetic bodies; Christian transhumanism

Has not science always been dreaming of resurrection and immortality, and does not science dream of it even more today when certain impossible things have become possible? We today cannot avoid noticing how much the risen body imagines bodily possibilities that are progressively realized by medical science and contemporary robotics, bionics, and biotechnology...-John Caputo $(2010,106)$

\section{Introduction}

The robotic revolution of the $21^{\text {st }}$ century will have massive effects on human societies, not least of which will be on religious worldviews. I have explored elsewhere the forthcoming ubiquity of caretaker robots for children and the elderly, their anticipated incorporation of religious software to ensure their ethical actions are consonant with their owners' religious affiliations, and their effect on religious beliefs and practices, particularly Christianity (McBride, 2016). The assimilation of robots into human families and religious communities as partners and fellow congregants challenges reliance on fundamental organic theology, such as Pauline blood sacrifice, and suggests a shift towards Johannine theology, based on the worship of the Word or Logos_far more amenable to machine systems (McBride, 2019). The challenge to Christian religion, however, will not be limited to the theological incorporation of robotic creatures into communities of the faithful.

\footnotetext{
${ }^{1}$ James McBride, Law, Ethics, History, and Religion, Global Liberal Studies, New York University, 10003, United States. Email: ejm12@nyu.edu.
} 


\section{Digitized replicants}

Recent scientific developments suggest that the status of human beings themselves may change radically. Neuroscientists have been working on methods to preserve the human brain in order to duplicate its synapses. The process is called "vitrifixation" by which technicians fix the brain at a particular moment in time by replacing blood in brain tissue with the chemical glutaraldehyde (Whiteman, 2018). The chemical embalms or "plasticizes" the brain in a state of vitrification, preventing any deterioration and making it possible to identify cerebral microstructures by cutting brain tissue into microscopic slices and examining such slices with an electron microscope (Fan, 2018). Theoretically, technicians could then identify and examine particular synapses and associated memories (Live Science, 2009). Created by neuroscientist Robert McIntyre, the company Nectome believes that it need not 'preserve the biological viability of brain tissue; the primary criterion for success is instead to maintain the delicate ultrastructural appearance of the brain' (McIntyre \& Fahy, 2015, 448). 21 ${ }^{\text {st }}$ Century Medicine, also associated with McIntyre, has reported notable progress in developing organ banking (Lewis et al., 2016), including the preservation of a rabbit brain (Kurzveil, 2016) and a pig brain (21 ${ }^{\text {st }}$ Century Medicine, 2018). The Nectome website declares that "[i]f memories can truly be preserved by a sufficiently good brain banking technique, we believe that within the century it could become feasible to digitize your preserved brain and use that information to recreate your mind" (Our Mission, 2018). Accordingly, through aldehyde-stabilized cryopreservation (ASC), it may someday be possible to upload a cerebral simulacrum of an individual into the cloud or perhaps a cyborgnetic body (Dvorsky, 2016).

Of course, this process of cryopreservation presents a number of significant problems. Science cannot currently image the brain at the synaptic level. Moreover, even if it did, the replication of the human connectome would be a Herculean feat since there are some 86 billion neurons in the human brain and 1,000 or more synaptic connections for each neuron, resulting in over 86 trillion synaptic contacts in total (Shermer, 2016). Finally, and most disturbingly, the cryopreservation of the brain requires the death of the living subject, a seemingly insurmountable obstacle save for jurisdictions which permit physician-assisted suicide (California, Colorado, Hawaii, Oregon, Vermont, Washington, and the District of Columbia in the United States, as well as Belgium and the Netherlands). By draining the blood from brain tissue and substituting glutaraldehyde, the process kills the brain while preserving its microstructures. Apart from the thorny philosophical problem of whether a digital version of a human being is in fact the same individual (Hayworth, 2018), even the most avid transhumanist might hesitate before offering his or her life for a chance at a digitized existence.

\section{Brains in a vat}

There is an alternative to the digital duplication of the human brain. The work of Kevin Warwick, the renowned English neuroscientist who became the first cyborg with bodily enhancements (Warwick, 2004), reported the possibilities of connecting a mass of brain cells via a computer interface with a robotic body (New Scientist, 2008). In these experiments, rat brain cells were disassociated from cortical tissue using enzymes and placed in an environment of warmth and nutrients. The chamber's electrodes, over which the brain cells were laid, established a connection between the cell mass and a mobile robot. Signal processing involves two-way communication between the culture and the robot. The closed loop system was 
tested by placing the Miabot robot in a box to determine whether sensory feedback to the rat brain cells would result in learned behavior such that the robot would become able to stop and turn rather than run into a wall. These experiments proved successful (Warwick, 2009).

Although these experiments echo the science fiction of The Matrix (Wachowskis, 1999), the film in which human beings, placed in pods, are connected to a virtual reality world, Warwick describes an interface between brain cells and a this-worldly material reality. Warwick's article is reminiscent of the thought experiment which became popular in philosophical circles during the 1980s and 1990s — the so-called "Brain in a Vat" controversy. In his book, Reason, Truth, and History, Hilary Putnam described a hypothetical situation in which we human beings were no more than brains in a vat (BIV) and, if so, whether we would know it (Putnam, 1981). Putnam's philosophical conundrum poses the age-old question of solipsism. Perhaps, if we are BIV, then we are suffering from a collective hallucination. However, Putnam was convinced that even though it may be totally consonant with human experience, the BIV hypothesis was "self-refuting" (Putnam, 1981, 15). In short, BIV could not possibly be true since, according to Putnam, language itself is based on external referents. Putnam's hypothesis launched a whole series of articles over the next two decades, arguing whether such a claim would in fact be self-refuting (Harrison, 1985; Steinitz, 1994; Forbes, 1995; Davies, 1995; Davies 1997). Of course, Putnam had his critics. Graeme Forbes argued that Putnam's refutation was manifestly "metalinguistic" (Forbes, 1995, 208) and grounded in a dubious "semantic externalism" (Forbes, 1995, 212). Yael Steinitz argued that a BIV could only know itself as an image of a BIV, but such knowledge would not necessarily mean that it is actually a BIV. It could be either a BIV or not (Steinitz, 1994, 214). As David Davies concluded, Putnam presumes the realist notion of truth. The conclusion simply echoes the presupposition (Davies, 1995, 203).

The BIV controversy served as a useful means to address the merits of radical skepticism. However, the experiments conducted by those researchers who work at the intersection of neuroscience and robotics are something altogether different. The question is not whether we are BIVs, but rather what will be the social and cultural consequences if and when we develop the technological capacity and the will to connect human brains to cyborgnetic bodies?

To be sure, research regarding the interface of brain cells and cyborgnetic bodies is only in its infancy and faces significant, if not insurmountable, problems. Scientists have made significant progress in developing an in vitro environment for human brain cells to advance research (Kelava \& Lancaster, 2016). Cultured from stem cells, brain "organoids" are small groups of brain cells which could serve as BIV; however, they die within a few months on their own (Pham et al., 2018). Neuroscientists have successfully integrated such human organoids with mouse brain cells, allowing those human brain cells to develop new neuronal connections (Mansour et al., 2018). In one experiment, “[o]rganoid grafts showed progressive neuronal differentiation and maturation, gliogenesis [to supply neurons with oxygen and nutrients], integration of microglia [for immune defense of brain cells], and growth of axons [for the transmission of neural messages] to multiple regions of the host brain" (Mansour et al., 2018, 432). In a different experiment, researchers were able to regenerate human neurons in vitro (Tang-Schomer et al., 2018). Remarkably, Italian neuroscientists have discovered that neurons extracted from donor mice could slow down their replicative senescence, or aging, and outlive the body of the original host (Magrassi et al., 2013). 
These studies suggest that in the distant future, it may be possible for neuroscientists to not only preserve human brains but to link them via a computer interface with cyborgnetic bodies. But if our cyborgnetic bodies were silicon, metals, and electronic networks, would we be the same? This question is similar to the classic argument of identity posed by the philosopher Robert Nozick (Nozick, 1983). If one were to replace the boards of a wooden vessel, the identity of the remodeled ship would remain the same, even if all the parts of the ship were so replaced, as long as it would be the "closest continuer" of the original (Nozick, 1983, 3435). Would the same go for the human body? Short of the wholesale substitution of the human body with a robotic analog, we could incrementally replace parts of the human body with cyborgnetic elements. As one philosopher has argued, "in the natural course of things, our organic bodies undergo full atomic replacement over some years, and we persons survive this total replacement without interruption in mental functioning. It seems possible that we could equally survive gradual replacement of organic cells by bionic cells — until finally the body that sustains us is no longer an organic body" (Baker, 2007, 338). If we accept such an argument, then why would the replacement of the human body with a cyborgnetic substitute be any different, as long as neuroscientists could maintain the existence of the individual's brain to which it was connected? These technological developments would undoubtedly have a farreaching impact upon human societies and cultures. My concern is to engage in a new BIV thought experiment, particularly as it affects the dominant religion of the West: Christianity.

\section{Resurrected bodies and Christian transhumanism}

The prospect that the human brain could outlive the body to which it was born-indeed, the possibility that it could live indefinitely-presents a fundamental challenge to seminal Christian beliefs. Christianity itself evinces a credo of immortality. In his First Letter to the Corinthians, Paul writes, "Where, O death, is your victory? Where, O death, is your sting?" (1 Cor. 15:55). The transhumanist vision seemingly would replace the Christian belief in immortality, making the latter obsolete or anachronistic, unless the transhumanist hope that brings together brain and cyborgnetic body could itself be construed in a Christian fashion.

The Symbolum Apostolicum, or Apostle's Creed, written circa 400 C.E., holds that the carnis resurrectionem or "resurrection of the body" and belief in vitam aeternam, or "life everlasting" are the sine qua non of Christianity (Knight, 2021). "If there is no resurrection of the dead, then Christ has not been raised," writes Paul, "and if Christ has not been raised, then our proclamation has been in vain and your faith has been in vain" (1 Cor. 15:13-14). Paul himself poses the question, "[w]ith what kind of body [soma] do they [the dead] come?" (1 Cor. 15: 35). Paul does not articulate precisely what constitutes this resurrected body. Indeed, for 2,000 years, Christians have disputed its meaning. Paul merely states that " $[\mathrm{w}]$ hat is sown is perishable, what is raised is imperishable" (1 Cor. 15:42). For Christians, one thing is certain. This resurrected body is not the same as the mortal flesh. As noted by the postmodern theologian John Caputo, the resurrected body differs from a "resuscitated body," as indicated by the raising of Lazarus (John 11:1-44) and Jairus's daughter (Mark 5:21-43; Matthew 9:1826; Luke 8:40-56). Neither Lazarus nor Jairus's unnamed daughter are immortal, but rather are restored to their "corruptible" bodies (Caputo, 2010, 95). Moreover, the resurrected body need not even have the same appearance, let alone the same substance, as mortal flesh. In one post-resurrection appearance story, two of Jesus' disciples on the road to Emmaus encounter but fail to recognize their Master, ironically leading them to explain to him the kerygma and the sect's beliefs (Luke 24:13-35). 
The nature of the resurrected body has been a topic of great debate among Christian philosophers and theologians. P.W. Gooch, for example, argued that "a Pauline resurrection body may well be ontologically the same as a disembodied person" (Gooch, 1981, 204). As oxymoronic as it might seem, Gooch suggests that the resurrected body is limited to 'consciousness and memory' and has no "extension in space" (Gooch, 1981, 204). Gooch ultimately defended his thesis by noting that the disembodied person is no different from the Christian notion of God, and therefore, to doubt one is to doubt the other. Nevertheless, the philosopher Bruce Reichenbach rejected Gooch's thesis, arguing that, in light of 1 Cor. 15:35 (see above cited passage), "soma cannot be interpreted simply in terms of psychical personality, but must have some intrinsic connection or link to the physical" (Reichenbach, 1982, 227). Accordingly, the resurrected body has a physical presence which manifests the same human person. "One can speak meaningfully about the identity of the deceased and re-created persons despite their discontinuity" (Reichenbach, 1982, 229). If the resurrected body is material, then a cyborgnetic body, which can be repaired indefinitely and linked to a BIV, could arguably be such a resurrected body.

This transhumanist vision, of course, presumes that the human brain could survive the human body, and therefore, if the criterion for mortality is "brain death," the individual could not have died. Therefore, according to Christian theology, the body, whatever its form, could not be resurrected. Although the cessation of neurological activity as a definition of death remains controversial (Mochella, 2016), "brain death" as a criterion for mortality would suggest that the fusion of a living brain and a cyborgnetic body could not raise a theological question of resurrected bodies since death did not occur. However, that conclusion presumes that a resurrected body requires the death of the brain. Paul himself wrote that "what you sow does not come to life unless it dies. And as for what you sow, you do not sow the body that is to be but a bare seed [gumnos kokkos] ..." (1 Cor. 15:36-37). If the "bare seed" is the human brain, then resurrection would first mandate its death. However, although this conclusion logically follows, it is not consonant with Paul's teaching. As John Caputo $(2010,95)$ has argued, "[f]or this transformation to occur one would not even, in principle, have to die-since it was Paul's expectation and that of the early Church that Jesus would return in their lifetime, and they would then all put on this immortality." Accordingly, the death of the brain is not a prerequisite for the resurrected body.

As a corpus unlike the mortal flesh (sarx), a cyborgnetic body might be considered a resurrected body. However, that would presume that the human brain, in religious terms, would be considered the locus of the soul. Western philosophers, theologians, and psychologists have expressed differing views about the soul and personal identity (Martin \& Barresi, 2006); however, there are those who identify the soul with the human brain. Charles Bonnet, the Enlightenment thinker, for example, argued that

We know that all bodies are impregnated by fire. It abounds in aliment. It is extracted from it by the brain, from whence it passes into the nerves. The seat of the soul, the immediate organ of feeling and thought, can be no other than a composition of this vital fire. The callous body, which we see and feel, must therefore only be the case or covering of the ethereal machine which constitutes the real seat of the soul (Bonnet, 1766, 73). 
This brain/corpus nexus echoes, to a certain extent, what has been called the "constitution view" of resurrected bodies. As the late philosopher Lynne Rudder Baker argued, this position shares the philosophical dualism of Descartes, who claimed that persons are not identical to their bodies (Baker, 2007). Nevertheless, to be a human person, one would have to be instantiated in a human body at least at some point in one's existence. "[ $] \mathrm{t}$ is necessary that human persons are embodied; but it is not necessary that they have the bodies that they in fact have" (Baker, 2007, 334). Baker herself speculated that, given the dualism between brain and body, a bionic body could be swapped for a human original and still remain the same human person. "I really do not like bizarre thought-experiments, but I think we are actually close to bringing this thought experiment to fruition... Moreover, it's easy to imagine billionaires seeking 'whole-body' replacements to prevent ageing” (Baker, 2007, 338).

Baker's Cartesian dualism was not without criticism. Andrei Buckareff and Joel Van Wagenen claimed that personal identity is predicated on the continuity of familiar physical states of the body (Buckareff \& Van Wagenen, 2010). For example, they contend that if a terminally ill man were to undergo a full body replacement with a donor who was color-blind or autistic, the recipient would not be the same since his perceptions of the world would be fundamentally different (Buckareff \& Van Wagenen, 2010, 128-129). Would the recipient be the same person, i.e., would he have the same first-person perspective (Buckareff \& Van Wagenen, 2010, 132)? Their criticism seems, however, to be particularly weak. Human beings undergo extensive changes to the human body that impact their perception of themselves and their surroundings, caused by everything from disease to bodily trauma to strokes; yet, we would not claim that their first-person perspective has fundamentally changed absent an irreversible coma.

A Cartesian dualist view of brain and body would seem to be compatible with a transhumanist theology of resurrected bodies. It would represent a new historical era. However, there may be those Christians who would reject the appropriation of the transhumanist vision. Indeed, they might regard "Christian transhumanism" as a distortion of the Christian message. Biofundamentalists, who oppose the development of the robotic and cyborgnetic age, might find favor with conservative Christians whose premillennialist beliefs predicate the resurrected body on the return of Jesus. However, the postmillennialist vision of the Second Great Awakening in America aimed to build a kingdom of God on earth (McLoughlin, 1980). A transhumanist Christianity, which embraces the postmillennialist desire to build a new epoch of peace and justice on earth, might revolutionize Christianity itself by promoting the quest for scientific knowledge and offering humans a cyborgnetic future.

\section{Conclusion}

Perhaps in the $22^{\text {nd }}$ century, scientific researchers will surmount the obstacle of death by preserving human existence through BIV technology and guaranteeing a continued physical existence with cyborgnetic bodies. Science would therefore set the stage for a new era in Christianity-one in which human beings would realize the kerygmatic promise of immortality. To reject this cyborgnetic future would not only unnecessarily condemn humans to an unwanted mortality but it may also signal the death of Christianity itself as an historical, yet transient, cultural phenomenon. 


\section{References}

$21^{\text {st }}$ Century Medicine. (2018). Special announcement: 21C in the news. 21 $1^{\text {st }}$ Century Medicine, Inc. wins the brain preservation prize for large mammals. $21^{\text {st }}$ Century Medicine. https://www. $21 \mathrm{~cm} . c 0 m /$ news.stm

Baker, L. R. (2007). Persons and the metaphysics of resurrection. Religious Studies, 43, 333-348.

Bonnet, C. (1766). The contemplation of nature (Vol. 1). The Royal Academies of London.

Buckareff, A.A., \& Van Wagenen, J.S. (2010). Surviving resurrection. International Journal for Philosophy of Religion, 67(3), 123-39.

Caputo, J.D. (2010). Bodies still unrisen, events still unsaid: A hermeneutic of bodies without flesh. In C. Boesel \& C. Keller (Eds.), Apophatic bodies: Negative theology, incarnation, and relationality (pp. 84-116). Fordham University.

Coogan, M.D. (Ed.). (2010). The new Oxford annotated Bible. New Revised Standard Version (4th ed.). Oxford University.

Davies, D. (1995). Putnam's brain-teaser. Canadian Journal of Philosophy, 25(2), 203-28.

Davies, D. (1997). Why one shouldn't make an example of a brain in a vat. Analysis, 57(1), 51-59.

Dvorsky, G. (2016). Brain preservation breakthrough could usher in a new era in cryonics. Gizmodo. https:/ /gizmodo.com/brain-preservation-breakthrough-could-usher-in-a-new-er-1758022181

Fan, S. (2018). The startup that has to kill you to preserve your brain— here's the science behind the buz:. Singularity Hub. https://singularityhub.com/2018/03/27/the-startup-that-has-to-kill-you-to-preserve-yourbrain-heres-the-science-behind-the-buzz/

Forbes, G. (1995). Realism and skepticism: Brains in a vat revisited. The Journal of Philosophy, 92(4), 20522.

Gooch, P. W. (1981). On disembodied resurrected persons: A study in the logic of Christian eschatology. Religious Studies, 17(2), 199-213.

Harrison, J. (1985). Professor Putnam on brains in a vat. Erkenntnis, 23(1), 55-57.

Hayworth, K. (2018). Vitrifying the connectomic self: A case for developing aldehyde stabilized cryopreservation into a medical procedure. Brain Preservation. http://www.brainpreservation.org/wp-content/uploads/ 2018/02/vitrifyingtheconnectomicself_hayworth.pdf

Kelava, I. \& Lancaster, M.A. (2016). Dishing out mini-brains: Current progress and future prospects in brain organoid research. Developmental Biology, 420, 199-209.

Knight, K. (Ed.) (2021). Apostles' creed. Catholic Encyclopedia. http://www.newadvent.org/ cathen/01629a.htm

Kurzveil, R. (2016). New cryopreservation procedure wins brain preservation prize. Kurzweil. Tracking the acceleration of intelligence. http://www.kurzweilai.net/new-cryopreservation-procedure-winsbrain-preservation-prize

Lewis, J.K., Bischof, J.C., Braslavsky, J.C., Brockbank, K.G., Fahy, G.M., Fuller, B.J., Rabin Y., Tocchio, A., Woods, E.J., Wowk, B.G., Acker, J.P., \& Giwa, S. (2016). The grand challenges of organ banking: Proceedings from the first global summit on complex tissue cryopreservation. Cryobiology 72, 169-182.

Live Science. (2009). Single brain cell can hold memory. Live Science. https://www.livescience.com/7653single-brain-cell-hold-memory.html

Magrassi, L., Leto, K., \& Rossi, F. (2013). Lifespan of neurons is uncoupled from organismal lifespan. In P. Rakic (Ed.), Proceedings of the National Academy of Sciences of the United States of America. www.pnas.org/content/110/11/4374

Mansour, A.A.F., Gonçalves, J.T., Bloyd, C.W., Li, H., Fernandes, S., Quang, D., Johnston, S., Parylak, S.L., Jin, X., \& Gage, F.H. (2018). An in vivo model of functional and vascularized human brain organoids. Nature Biotechnology, 36, 432-41.

Martin, R. \& Barresi, J. (2006). The rise and fall of soul and self: An intellectual history of personal identity. Columbia University Press.

McBride, J. (2016). Robotic bodies and the Kairos of soulless theologies. The Ways of Knowing Conference. Harvard Divinity School, Cambridge, MA. 
44 'Where, O Death, Is Your Sting?'

McBride, J. (2019). Robotic bodies and the Kairos of humanoid theologies. Sophia, International Journal of Philosophy and Traditions, 58, 663-678.

McIntyre, R. L. \& Fahy, G.M. (2015). Aldehyde-stabilized cryopreservation. Cryobiology, 71(3), 448-458.

McLoughlin, W.G. (1980). Revivals, awakening and reform. University of Chicago.

Mochella, M. (2016). Deconstructing the brain disconnection-brain death analogy and clarifying the rationale for the neurological criterion of death. Journal of Medicine and Philosophy, 41, 279-299.

New Scientist. (2008). Robot with a rat brain. YouTube. https://www.youtube.com/watch?v=10eZytv6Qk

Nozick, R. (1983). Philosophical explanations. Belknap.

Our Mission. (2018). Nectome. https://nectome.com/about-us/

Pham, M.T., et al. (2018). Generation of human vascularized brain organoids. NeuroReport, 29, 588-93.

Putnam, Hilary. (1981). Reason, truth and history. Cambridge University Press.

Reichenbach, B.R. (1982). On disembodied resurrected persons: A reply. Religious Studies, 18(2), 22529.

Shermer, M. (2016). Can our minds live forever? Can a brain's connectome be preserved forever? Scientific American. www.scientificamerican.com/article/can-our-minds-live-forever/

Steinitz, Y. (1994). Brains in a vat: Different perspectives. The Philosophical Quarterly, 44(175), 213-22.

Tang-Schomer, M.D., Wu, W.B., Kaplan, D.L., \& Bookland, M.J. (2018). In vitro 3D regeneration-like growth of human patient brain tissue. Journal of Tissue Engineering and Regenerative Medicine, 12(5), 1247-60.

Wachowskis. (1999). The Matrix [Film]. Warner Bros. et al.

Warwick, K. (2004). I, cyborg, University of Illinois Press.

Warwick, K. (2009). Of mice and men. In R.G. Bushko (Ed.), Strategy for the future of health (pp. 209-213). IOS Press.

Whiteman, H. (2018). Your brain could be backed up, for a deadly price. Medical News Today. www.medicalnewstoday.com/articles/321235.php 